\title{
NOTES ON NEW OR RARE SPECIES OF RAVENELIA
}

\author{
W. H. LoNG
}

While on recent field work in Texas, the writer collected several very interesting species of Ravenelia. Some of them are undescribed, while others have heretofore been known only from their type collections. Several of them are Mexican, while one is a South American species.

\section{Ravenelia hoffmanseggiae, sp. nov.}

O. Pycnia unknown.

II. Uredinia amphigenous, scattered, orbicular to irregularly oval, liver brown ${ }^{\mathrm{I}}$ subepidermal, ruptured epidermis prominent; paraphyses none; urediniospores obovate, ellipsoid to subglobose, I6-25 by $25-30 \mu$, average for 10 spores 19.7 by $26.7 \mu$, walls thin, I-I.5 $\mu$, uniform in thickness and concolorous, capucine buff in color, sparsely and minutely echinulate when dry but appearing as if smooth when wet; germ pores 8, situated in two irregular rows of 4 each, one row subequatorial, the other near apex of spore, in the subglobose spores the germ pores appear as if scattered.

III. Telia unknown.

On Cassiaceae. Type collected on Hoffmanseggia oxycarpa at Del Rio, Texas, November 6, I9I6, by W. H. Long (no. 6082). ${ }^{2}$ This is the first collection of Ravenelia to be reported on this host, although the genus Hofmanseggia is widely distributed throughout those regions where species of Ravenelia flourish.

\section{Ravenelia siderocarpi, sp. nov.}

O. Pycnia unknown.

II. Uredinia amphigenous but mainly epiphyllous, scattered, bullate to oval, $0.1-0.8 \mathrm{~mm}$. across, often in a circle around a central sorus, chestnut-brown, subcuticular, long covered by the cuticle, ruptured cuticle very prominent; paraphyses none;

${ }^{I}$ RIDGWAy, RoBert, Color standards and color nomenclature. pp. 43. pls. 53 . Washington, D.C. I9r2.

${ }^{2}$ Unless otherwise stated, all herbarium numbers cited in this article refer to the herbarium numbers of the writer. 
urediniospores obovate, obovate-elliptical to subpyriform, I5-18 by $25-37 \mu$, average for 20 spores 16.9 by 3 I . $7 \mu$, walls ochraceoustawny, concolorous, thick, $2 \cdot 5-3 \cdot 5 \mu$, apex but slightly if at all thickened, echinulate; germ pores prominent, 6 in equator.

III. Telia amphigenous, usually epiphyllous, sparse, scattered, small, $0.1-0.5 \mathrm{~mm}$. across, bullate to elliptical, subcuticular, blackish-brown, tardily naked, ruptured cuticle very conspicuous; paraphyses none; teliospore heads chestnut-brown, subglobose, $40-60 \mu$ in diameter, average for 20 heads $50.5 \mu, 2-4$ spores across, $5^{-10}$ spores to each head, $4^{-8}$ marginal, o-3 inner spores, usual number of spores per head $7-8$, each spore bearing $3-6$ short hyaline tubercles $3-5 \mu$ long; cysts few, $4-8$, as many as the marginal spores, subglobose, subpendant around pedicel, not cohering, easily swelling and bursting in water; pedicel hyaline, short, deciduous, compound.

On Mimosaceae. Type collected on Siderocarpos flexicaulis 6 miles from Brownsville, near Tandy's Switch, Texas, November II, I916, by $W$. $H$. Long (no. 6174). This Ravenelia is very abundant on this host in the Texas ebony jungles in the immediate vicinity of Brownsville. It is probably common wherever its host is found in sufficient quantity to form thickets.

\section{Ravenelia prosopidis, sp. nov.}

O. Pycnia unknown.

II. Uredinia sparse in material examined, small, amphigenous, mainly epiphyllous, often in a circle around a central sorus, $0.5^{-}$ I. $0 \mathrm{~mm}$. across, narrowly elliptical to oval, subepidermal, long covered by the epidermis, ruptured epidermis very prominent; urediniospores oval to subpyriform, $\mathrm{I}_{3}-20$ by $24-4 \mathrm{I} \mu$, strontium yellow, average for 40 spores, 16.9 by $3^{1} .6 \mu$; walls $\mathrm{I} \cdot 5^{-2} \mu$ thick, apex slightly darker and thicker, verrucose-echinulate, germ pores 4-6 in equator; paraphyses abundant, of two types, the usual form capitate, the other broadly clavate, in a dense ring around the sorus, also intermixed with the spores, heads of capitate paraphyses madder brown, walls thickened at apex, stipe amber yellow to hyaline, solid, $12-27$ by $28-85 \mu$, average for $40,16.84$ by $55 \cdot 5 \mu$, clavate paraphyses I0-13 by $25-45 \mu$, average for Io, I3 6 by $39 \mu$.

III. Telia amphigenous, mainly hypophyllous, Vandyke brown, usually in a circle around a central sorus, $0.5^{-1.0 ~ m m}$. across, 
elliptical to oval, subepidermal, early naked, ruptured epidermis very prominent; teliospore-heads tawny, depressed hemispherical, often concave at top, $75^{-118} \mu$, average for 40 heads $94 \mu$, 6-io spores across, 20-28 marginal spores, I6-40 inner spores, usual number for head 46-54 spores in all; heads papillate, with one, rarely two, papillae to each spore, papillae ranging from mere tubercles near top of head to blunt papillae $4-7 \mu$ long around margin, top of heads often free from papillae, many heads with only a few tubercles on entire head, papillae light brown; paraphyses very abundant in a dense circle around the telia, also scattered throughout the sorus, similar to those found in the uredinia, often sori occur which are composed mainly of paraphyses; cysts numerous, pendant in 2 or 3 rows around the pedicel, subglobose, about as many as marginal spores, easily swelling and bursting in water; pedicel compound, deciduous, hyaline to faintly fulvous, short.

On Mimosaceae. Type collected on Prosopis juliflora at Denton, Texas, October 10, 1907, by $W . H$. Long (no. 2013); also collected on same host and in same locality in 1908 by Long (no. 4870). A part of the type material of this Ravenelia was issued in Fungi Columbiani, E. BarTHoLomew, no. 268r, as Ravenelia arizonica Ellis and Ev.

Ravenelia prosopidis is closely related to $R$. arizonica, but differs from this species in the very irregular length of its papillae and in having some teliospore heads nearly smooth. Its telia are also encircled by a dense layer of paraphyses, while none or but very few paraphyses are found in the telia of $R$. arizonica. This species will probably be found throughout northern Texas within the range of its host. It is sometimes associated on the same leaves with Neoravenelia holwayi, at least some telia were found which contained teliospores with heads entirely smooth, while other and adjacent sori contained the typical papillate heads of $R$. prosopidis.

\section{RAVENELIA ROEMERIANAE Long}

O. Pycnia sparingly present, amphigenous and fruticolous, in orbicular groups of $6-20$, groups $0.5^{-1.0} \mathrm{~mm}$. across, usually surrounded by a circle of uredinia, blackish-brown, flattened hemispherical, $70-105 \mu$ across, $25^{-38} \mu$ tall.

II. Uredinia usually fruticolous but also amphigenous, occasionally caulicolous and in very rare cases forming slight witches' 
brooms, often densely confluent on both sides of the pods over areas $\mathrm{I}-5 \mathrm{~cm}$. across, individual uredinia on pods elliptical to irregularly oval, $0.2-0.6 \mathrm{~mm}$. across, verona brown to tawny-olive in color, uredinia on leaves amphigenous, elliptical to irregularly oval, primary uredinia often encircling pycnia; urediniospores obovate-oblong to linear-oblong, on pods IO-I 7 by $27-45 \mu$, average for 20 spores $\mathrm{I} 3$ by $3 \mathrm{I} \mu$, on leaves urediniospores are IO-I 4 by $27-38$, average for 20 spores $\mathrm{I}_{3}$ by $33 \mu$, average for both sets of spores $\mathrm{I} 3$ by $32 \mu$; walls $\mathrm{I}-\mathrm{I} \cdot 5 \mu$ thick, slightly thicker above (about $3 \mu$ ), prominently but sparsely echinulate, spinules very sparse on upper third of spore, upper third golden brown to wine color, remainder of spore paler to hyaline, germ pores 8 , in 2 rows of 4 each, upper row at boundary of colored and hyaline part of spore, lower row about the same distance below the equator; paraphyses abundant, intermixed with the urediniospores, clavate to clavate-capitate, $35-50 \mu$ long, average length for $10,44.0 \mu$, heads $9-13 \mu$, average for Io heads $10 \mu$, apex of head thickened about $3 \mu$, pale fulvous, stipe usually thin-walled, hyaline.

III. Telia amphigenous, often abundant on all parts of badly infected leaves, scattered, subcuticular, blackish, shining, 0.2I. $2 \mathrm{~mm}$. across, irregularly oval, ruptured cuticle noticeable; teliospore heads blackish, $6_{3}-100 \mu$, average for 30 heads $78 \mu$, 5-7 cells across, $14-30$ spores in each head, 8-14 marginal spores and 6-I5 inner ones, verrucose, each spore bearing 3-10 colorless warts about $2 \mu$ tall by $3 \mu$ broad; paraphyses present and similar to those in uredinia; cysts of same number as marginal spores, flattened, appressed beneath head, extending from periphery to pedicel, in one row, united laterally, ovoid to oblong-ovate, slow to burst in water; pedicel short, colorless, compound, deciduous.

Distribution.-Texas: On Acacia roemeriana, San Marcos (type locality), Long, in November r915 (nos. 5494 and 5498 type), in May I916 (nos. 6009, 6019, 6020, and 6065); San Antonio, Long, in May 1916 (nos. 5610, ${ }_{56}^{611}, 561_{2}, 561_{4}$, and $561_{5}$ ), and in November 1916 (nos. 6155 and 6159 ); Uvalde, Heald and Wolf, in August 1909 (no. 6243); Long, in November Igr6 (nos. 6145 and 6r48).

The type of Ravenelia roemerianae was collected on Acacia roemeriana at San Marcos, Texas, in November 1915, but on account of the lateness of the season this material did not contain any uredinia. In May 1916, the writer 
visited the type locality of this rust at San Marcos and found an abundance of uredinia, especially on the pods. Some uredinia as well as pycnia were also found on the leaves. Even at that early date telia were developing and the uredinia on the leaves were disappearing. The uredinia which were so abundant on the pods in May weathered and disappeared so that none were found on the pods in November of the same year.

The writer has seen several thousand trees of Acacia roemeriana infected with this Ravenelia in various places in Texas, and only two trees of this entire number showed any evidence of witches' brooms. One tree was found at San Antonio and the other at Uvalde, Texas. There were some ro-1 5 witches' brooms on each of these two trees. Apparently the germination of the teliospores of this rust occurs when the pods are young and easily infected and yet not at the right season to infect the young branches and cause witches' brooms.

This rust is closely related to Ravenelia versatilis (Peck) Dietel, a fact noted in a previous article ${ }^{3}$ by the writer. Table I gives a brief comparison of the more salient characters of each of these two species of Ravenelia. From this table the main differences between the two species are easily seen.

Ravenelia roemerianae has been collected by the writer in several places in Texas and probably occurs wherever the host is present. The rust was exceedingly abundant in the vicinity of Uvalde, Texas, in November rgr6. Every tree of Acacia roemeriana examined by the writer in the mesquite (Prosopis juliflora)-catclaw (Acacia roemeriana) flats was heavily infected; in fact every leaf on most of the trees was practically covered with the blackish telia of this rust.

Ravenelia mesillana Ellis and Barth. Bull. Torr. Bot. Club 25: 508 . 1898

(Ravenelia longiana Sydow, Hedwigia Beibl. 40:I28. I9or)

O. Pycnia, appearing before the uredinia, sparse, amphigenous, in circinating, crowded, orbicular groups $2-4 \mathrm{~mm}$. across, subcuticular, Brussels brown, depressed hemispherical, 40-60 $\mu$ tall by roo-r $65 \mu$ broad.

II. Uredinia amphigenous, mainly hypophyllous, scattered, tawny, oval to elliptical, $0.5^{-1} .0 \mathrm{~mm}$. in diameter, early naked, pulverulent, subcuticular, ruptured cuticle very noticeable; urediniospores oval to subglobose, $\mathrm{I}_{5}-22$ by $20-26 \mu$, average for 20 spores I9 by $23 \mu$; walls $2-3 \mu$ thick, tawny-olive, sparsely echinulate, germ pores 6-8, scattered; paraphyses very few, intermixed with

${ }^{3}$ Long, W. H., Five undescribed species of Ravenelia. Bot. Gaz. 6r:416-424. I9r6. 


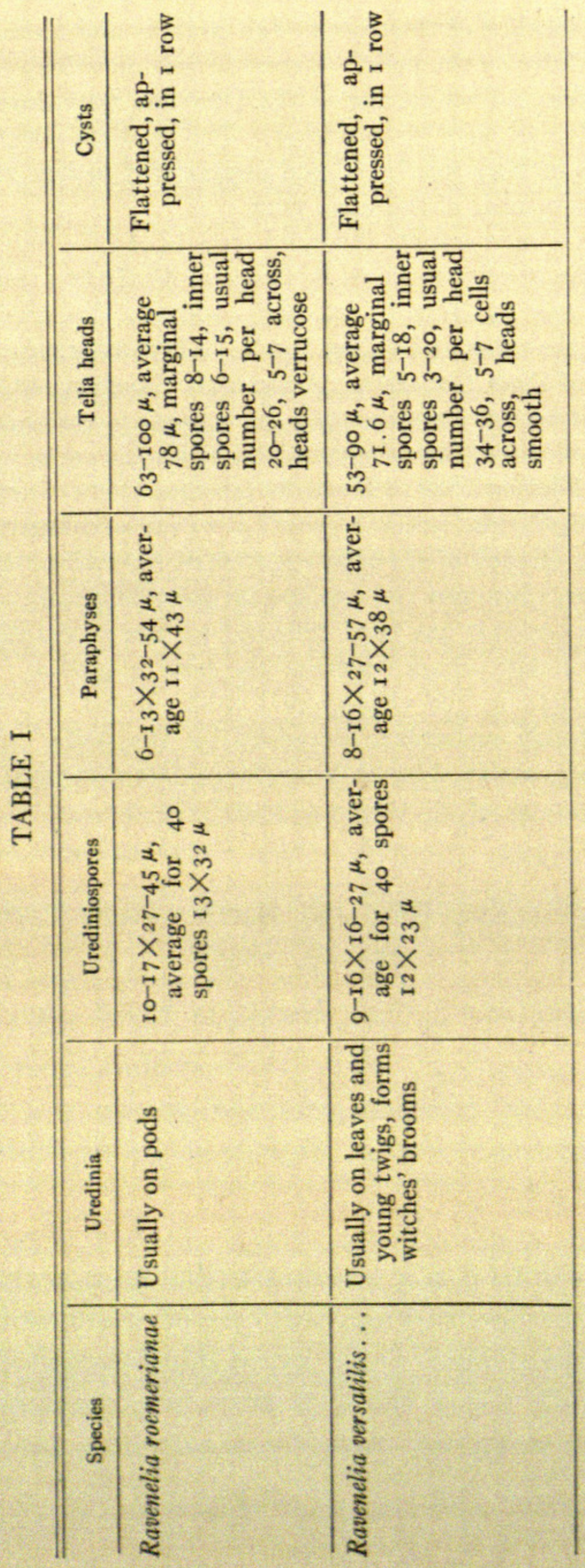


the spores, colorless, clavate to subcapitate, $5^{-14}$ by $35^{-62} \mu$, average for $20,9.6$ by $45 \mu$, apex of head thin-walled, base of head very thick-walled, stipe usually solid.

- III. Telia amphigenous, scattered, $0.5^{-1} .0 \mathrm{~mm}$. across, often confluent over areas $3-4 \mathrm{~mm}$. in diameter, brownish-black, elliptical to irregularly oval, subcuticular, ruptured cuticle very conspicuous; teliospore heads dark chestnut-brown, hemispherical, smooth or an occasional head with a few scattered, short $(2-3 \mu)$, hyaline, tubercles, especially on the marginal spores, $5-9$ cells across, 60$90 \mu$, average for 20 heads $74 \mu$, 10-20 marginal spores, 8-24 inner spores, usual number per head 24-32; paraphyses present but very few and similar in every way to those found in the uredinia; cysts hyaline, in 2-3 rows around the pedicel, many, not coherent with each other, slow to burst in water, subpendant; pedicel colorless, compound, short, deciduous.

This description of the rust was drawn from material on Cassia roemeriana.

Distribution.-New Mexico: On Cassia bauhinioides, Mesilla Park, Wooton, in October I895, ex. Herb. N.Y. Bot. Garden (no. 5021 Long) and ex. Herb. A. and M. College of N. Mex. (no. 5022 Long); Wooton in October 1897, North American Fungi, Herb. of Elam Bartholomew (part of type material, no. 5025 Long); mesa west of Organ Mountains, F. C. Werkenthin, in October rgr6 (no. 5480 Long); Texas: On Cassia roemeriana, Austin, November 1897 (no. 5039), type material for Ravenelia longiana, Long, in August 1901 and October I915 (nos. Iorg and 548I); Llano, Heald and Wolf, August I 909 (no. 175I Herb. Path. and Myc. Investigat., Plant Disease Survey); Marble Falls, Carsner and Studhalter, May I9r 2 (no. 4333 Herb. Univ. Texas); Meridian, Long, June I916 (no. 6056); San Antonio, Long, May and November I9r6 (nos. 5616 and 6r68); San Marcos, Long, November 1915, and May I9I6 (nos. 5468 and 6034).

This Ravenelia was first collected on Cassia bauhinioides at Mesilla Park, New Mexico, in 1895 and again in 1897 by Wooron. It was described as a new species by Ellis and BARTHolomew from the New Mexico material collected in 1897 . It has been reported on this host only from the type locality. In I900, the writer sent SyDow a Ravenelia on Cassia roemeriana, collected at Austin, Texas, in 1897 . From this material he described as new, Ravenelia longiana.

In recent investigations on the genus Ravenelia, the writer's attention was called, not only to the marked resemblance of $R$. mesillana to $R$. longiana, but also to the close relationship of the two host plants, Cassia bauhinioides and C. roemeriana. The only appreciable difference heretofore reported between the two rusts was the supposed fact that Ravenelia mesillana had no paraphyses, 
while $R$. longiana had a few hyaline ones. The writer has material from the type collections of both of these species, and a careful examination of this material shows that not only do both species have paraphyses, but that the paraphyses are identical in every respect and are present in the telia of the type material of both $R$. mesillana and $R$. longiana. A careful study of the other salient characters of these rusts has convinced the writer that they are identical in every respect and therefore should be considered as only one species.

In recent field work in Texas, the writer collected the pycnidial stage on Cassia roemeriana of what has heretofore been known as Ravenelia longiana.

\section{RAVENELIA SILIQUAE Long}

O. Pycnia unknown.

II. Uredinia hypophyllous and caulicolous, on the leaves scattered, elliptical, $0.5^{-1} .0 \mathrm{~mm}$. across, pulverulent, subcuticular, early naked, sudan brown, ruptured cuticle not prominent, uredinia on the woody twigs and branches perennial, very inconspicuous, elliptical, $0.5^{-5} \mathrm{~mm}$. long by $0.5^{-2} \mathrm{~mm}$. broad; urediniospores obovate, elliptical to rarely oblong, on the leaves $\mathrm{I}_{3}-\mathrm{I} 7$ by $20-27 \mu$, average for Io spores $\mathrm{I} 4.4$ by $2 \mathrm{I} \mu$, urediniospores on branches I I-I 6 by $I 7-27 \mu$, average for 20 spores $I 3.4$ by $22.5 \mu$, urediniospores on both leaves and branches buff yellow; walls $I \cdot 5^{-2} \cdot 5 \mu$ thick, concolorous, not thickened at apex, densely and strongly verrucose, germ pores 8 , in two transverse zones of four each, equidistant from the equator; paraphyses abundant, intermixed with the spores, clavate to subcapitate, often curved, 7-10 by $50-67 \mu$, average for Io paraphyses 9.5 by $62 \mu$, heads pale fulvous to hyaline, stipe slender, usually solid, hyaline, paraphyses in sori on woody branches few, 6-I I by $25-49 \mu$, average for 20 paraphyses 8.3 by $38 \mu$.

\section{Telia unknown.}

On Mimosaceae: Distributed as follows: Texas, on Acacia farnesiana, San Antonio, Long, November I9I6 (no. 6153); W. H. Mercer, February 1917 (no. 6263); Mexico, on Acacia farnesiana, Etla, Oaxaca, Holway, October 1899, no. $384 \mathrm{I}$ of Holway (type); Hawaii, on Acacia farnesiana, Honolulu, Harold L. Lyon, January 1913, no. 164, Sydow, Fungi exotici exsiccati.

The rust on the pods of this host from Hawaii agrees very closely with the Mexican type material. There are a few minor differences in the characters of this rust when on leaves and stems and when on the pods, but they are not sufficient in the judgment of the writer to constitute a new species. From the foregoing distribution it is seen that since this Ravenelia was described in 1903 
on the pods of Acacia farnesiana from Mexico, the rust has been collected in Texas on the leaves and woody branches of this host and in Hawaii on the pods. It was probably introduced into Hawaii on nursery stock which contained infected woody branches. Apparently Ravenelia siliquae does not have a telial stage, since only uredinia have ever been found, although this rust has been collected during October, November, January, and February on pods, leaves, and woody branches, and in three countries, namely, United States, Mexico, and Hawaii.

\section{Ravenelia australis Diet. and Neg.}

O. Pycnia unknown.

II. Uredinia amphigenous, very small, punctiform to irregularly oval, less than $0.5 \mathrm{~mm}$. across, subepidermal, soon naked, ruptured epidermis inconspicuous; urediniospores obovate, ellipticobovate to subpyriform, light cinnamon brown, I3-20 by $25-32 \mu$, average for 20 spores $\mathrm{I} 6.6$ by $28.2 \mu$; walls $\mathrm{I} .5^{-2} .0 \mu$ thick, slightly or not at all thickened above, concolorous, echinulate, germ pores $4-6$, equatorial; paraphyses very abundant, incurved, dense, encircling the sori, ferruginous, hyphoid, more or less curved near apex, I0- 17 by $50-67 \mu$, average for to paraphyses 12.5 by I $4.4 \mu$, walls about $2.5 \mu$ thick, an occasional paraphysis clavate, nearly colorless and with a solid stipe.

III. Telia amphigenous, punctiform to irregularly oval, less than $0.5 \mathrm{~mm}$. across, blackish-brown, subepidermal, early naked, ruptured epidermis inconspicuous; paraphyses very abundant, encircling the sori and similar to those found in the uredinia; teliospore heads chestnut-brown, hemispherical, 67-1 10 $\mu$ across, average for 20 heads $92.3 \mu, 7^{-1}$ I cells across, I8-30 marginal spores, 22-64 inner ones, 40-94 spores per head, smooth; cysts small, numerous, subglobose, subappressed, beneath entire head, in two rows, swelling and easily bursting in water; pedicel short, hyaline, deciduous.

On Mimosaceae.-The following collections were made by the writer in Texas, all on Acacia farnesiana: Uvalde, November ${ }_{19}{ }_{6} 6$ (nos. 6r 50,6 I 51 , and 6r52); San Antonio, November rgr6 (no. 6r65). The above is a description of rust as it occurs in Texas.

This species of Ravenelia has heretofore been known only from its type locality in South America (Concepcion, Chile), where it was found on Acacia cavenia, now recognized as a synonym for $A$. farnesiana (Vachellia farnesiana). 
The writer has not been able to obtain authentic material of this South American Ravenelia, nevertheless he is assigning to this species the Texas Ravenelia collected on the same host ( $A$. farnesiana), since its characters are practically identical with those described for the South American plant.

\section{RAVENELIA GRACILIS Arth.}

O. Pycnia not found in the Texas material.

II. Uredinia epiphyllous, seated on slightly pallid areas, scattered, very small, less than $0.4 \mathrm{~mm}$. across, elliptical to irregularly oval, tardily naked, subepidermal, ruptured epidermis prominent; urediniospores ovate, ovate-fusiform to somewhat flask-

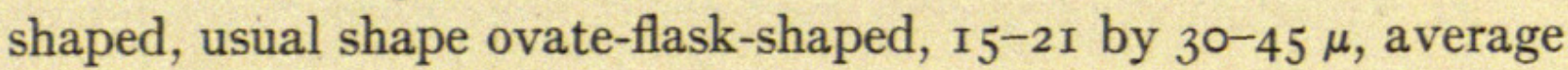
for 20 spores 18.4 by $37.6 \mu$; walls $2-2.5 \mu$ thick, russet colored, sparingly echinulate, apex darker and slightly thickened, germ pores 4-6, in equator; paraphyses few, peripheral and also intermixed with the spores, hyphoid to subclavate, hyaline, walls thin, 4-7 by $35-50 \mu$.

III. Telia epiphyllous, similar in size and shape to the uredinia, blackish-brown, subepidermal; teliospore heads dark chestnutbrown, hemispherical, $60-87$ by $37-40 \mu$ thick, average for 20 heads 73.8 by $39 \mu, 5^{-6}$ spores across, $8-\mathrm{I} 4$ marginal spores, $4^{-\mathrm{I} 2}$ inner spores, usual number per head 22-24, each spore on lower part of head bearing 2-4 small, hyaline tubercles, 2-5 $\mu$ long, upper portion smooth, or with I-4 very short tubercles to each spore; cysts in I row, subglobose, few, as many as the marginal spores, united laterally and extending from periphery to stipe, subappressed, easily swelling and bursting in water; pedicel short, deciduous, colorless.

Collected on Havardia brevifolia 4 miles from Brownsville, Texas, near Tandy's Switch, November 10, 1916, by W.H. Long (no. 6r6o). This description was made from material collected at Brownsville, Texas.

This rust has heretofore been known only from the type collection which was made at San Luis Potosi, Cardenos, Mexico, on an unknown host. The writer recently collected at Brownsville, Texas, what appears to be the same species. A careful comparison of the type material collected by HoLwAy in Mexico with the Brownsville rust shows no essential characters sufficient to warrant making a new species of the Texas Ravenelia. A study of the Mexican

4 The writer is under obligations to Dr. J. K. SMaLL, of the New York Botanical Garden, for identifying this host and the host of Ravenelia hoffmanseggiae. 
host and of the host found at Brownsville shows that the two are apparently identical. Ravenelia gracilis was rather common in the vicinity of Brownsville wherever the host occurred in any quantity. In the original description of this species the urediniospores are given as obovate and the teliospore heads as bearing 4-7 colorless tubercles to each spore. The writer, however, failed to find any obovate urediniospores in that portion of the type collection which is in his herbarium. The teliospore heads of the type show many heads with smooth tops but with short tubercles around the margin, while other heads in the same mount have shorter and fewer warts to each spore at the top than on the margin, thus agreeing in every detail with the Brownsville material.

\section{Ravenelia leucaenae Long}

This species was collected by the writer near Brownsville, Texas, on Leucaena pulverulenta. There are certain minor characters of this rust not given in the published description of it that are worth recording. The urediniospores on this host are mainly concolorous, often with the apex slightly thickened. The teliospore heads are $5^{-6}$ cells across, with $5^{-16}$ marginal spores and $3^{-14}$ inner ones, usual size $14-16$ spores per head, each spore at top of head bears from $\circ$ to $2-4$ very short tubercles, while there are $4^{-6}$ straight or slightly curved tubercles, $4-6 \mu$ long, on each marginal spore; cysts as many as marginal spores, appressed, extending from periphery to pedicel.

This Ravenelia has been reported from Mexico on the following host species: Leucaena sp., L. diversifolia, and $L$. esculenta.

\section{Neoravenelia holwayi (Dietel) Long}

II. Uredinia caulicolous, forming large, woody, perennial, fusiform galls, I- $-8 \mathrm{~cm}$. thick by $4-\mathrm{I} 2 \mathrm{~cm}$. long, densely confluent over large areas on the galls, subepidermal, argus brown; urediniospores oblong-linear, obovate, elliptical, clavate to subpyriform, usual shape obovate to subclavate, $\mathrm{I} 3-24$ by $26-53 \mu$, average for $\mathrm{I} 20$ spores $I 7$ by $36 \mu$; walls $2-3 \mu$ thick, slightly thickened above, sudan brown, often lighter to subhyaline below the equator, echinulate, germ pores $4-6$ in equator; paraphyses few, capitate. or sometimes clavate-capitate, $I_{3}-22$ by $30-65 \mu$, average for Io paraphyses 17.6 by $46.3 \mu$, heads intensely colored, deep chestnut-brown to liver brown, nearly solid, stipe hyaline or faintly tinted. 
III. Teliospores intermixed in uredinia on the galls; teliospore heads liver brown, hemispherical, often depressed, smooth, 6oI $30 \mu$, average for 40 heads I0 $3 \mu, 8-{ }_{2}$ spores across, 20-38 marginal spores, $40-78$ inner ones, average number of spores in each head 84-94; cysts globose to subglobose, in 2-3 rows, pendant beneath entire head, not coherent, slow to burst in water; pedicel hyaline or slightly tinted, short, deciduous, compound. This is a description of the gall-producing form of Neoravenelia holwayi.

For several years the writer has been finding a species of Ravenelia on mesquite (Prosopis juliflora) which produces large, fusiform, woody galls. At first this rust was referred to Ravenelia arizonica, but a careful examination of the galls revealed the presence of teliospores with smooth heads. These smooth teliospores were so constantly found associated with certain types of galls that the writer made a special study of the galls found on mesquite. This investigation showed that there was a Ravenelia present on galls throughout a certain zone which constantly produced smooth teliospore heads. A careful study of the Ravenelia on these galls failed to show any positive differences either in the urediniospores or teliospores which would separate this gall-forming species from the ordinary leaf form of Neoravenelia holwayi. There are wide variations in shape and size of the urediniospores, as is to be expected when growing on galls as compared to those found on the leaves.

The galls were found in localities where the leaves of the mesquite were abundantly infected with the usual form of $N$. holwayi. In the vicinity of San Antonio and Uvalde the galls were rare, but at Corpus Christi and Brownsville they were rather common. From Del Rio west to New Mexico and Arizona all of the galls found on the mesquite were of a different type and were associated with the teliospores of Ravenelia arizonica. The galls produced by Neoravenelia holwayi are smoother and more fusiform than those caused by Ravenelia arizonica. In $R$. arizonica the galls are rather brittle, due to the large amount of parenchyma tissue developed in the gall. On weathering, even when alive these galls have deep transverse fissures in their surfaces. The galls produced by Neoravenelia holwayi are very woody, rather smooth, do not develop many fissures, but form round wartlike knobs on the older galls, on which are borne the urediniospores and teliospores. But few sori of any kind were found on galls collected as late as November. The surface of the galls where the sori once were borne had healed over, except here and there a sorus was left which contained both urediniospores and teliospores.

The writer is placing this gall-producing form provisionally under Neoravenelia holwayi, since at the present time no evidence is at hand sufficient to justify separating this gall form from the typical $N$. holwayi. Further investigation and study of this rust may show that its aecial stage is not of the Caeoma type as is $N$. holwayi, in which case it would belong to the genus Ravenelia and 
would be an undescribed species. As it now stands, this species parallels Ravenelia arizonica, both species having a leaf and a gall form; the galls of each usually bear only urediniospores, while teliospores are rarely found on the galls but usually occur on the leaves.

Type material of each of the 3 new species of Ravenelia described in this paper has been deposited in the Pathological and Mycological Collections of the Bureau of Plant Industry, Department of Agriculture, Washington, D.C.

OfFice of INVESTIGations IN

Forest Pathology

BUREAU OF Plant INDUSTRY

AlbuquerQue, N.M. 


\section{$2 \mathrm{BHL}$ Biodiversity Heritage Library}

Long, W. H. 1917. "Notes on New or Rare Species of Ravenelia." Botanical gazette 64(1), 57-69. https://doi.org/10.1086/332085.

View This Item Online: https://www.biodiversitylibrary.org/item/109348

DOI: https://doi.org/10.1086/332085

Permalink: https://www.biodiversitylibrary.org/partpdf/223897

\section{Holding Institution}

Missouri Botanical Garden, Peter H. Raven Library

\section{Sponsored by}

Missouri Botanical Garden

\section{Copyright \& Reuse}

Copyright Status: Public domain. The BHL considers that this work is no longer under copyright protection.

This document was created from content at the Biodiversity Heritage Library, the world's largest open access digital library for biodiversity literature and archives. Visit BHL at https://www.biodiversitylibrary.org. 